\title{
Ks. Wojciech Góralski, Adhoracja apostolska Amoris laetitia papieża Franciszka. Prezentacja dokumentu z komentarzem do nn. 300-308, Płocki Instytut Wydawniczy, Płock 2016, 106 ss.
}

Publikacja wydana nakładem Płockiego Instytutu Wydawniczego stanowi zwięzłą prezentację adhortacji apostolskiej Amoris laetitia wprowadzając czytelnika w kluczowe zagadnienia poruszone przez Ojca świętego, wraz z komentarzem do nn. 300-308 adhoracji poświęconych problemowi udziału w życiu sakramentalnym Kościoła małżonków żyjących w związkach „nieregularnych”, tj. rozwiedzionych i trwających w nowych związkach.

To już kolejny raz kiedy Autor podejmuje tę problematykę - w tym roku wydana została również jego praca pt.: Sprawiedliwość czy miłosierdzie? Problem Komunii świętej katolików rozwiedzionych i żyjących $w$ małżeństwie cywilnym, w której odpowiada na pytanie, czy w stosunku do małżonków rozwiedzionych i żyjących w nowym związku Kościół winien się kierować miłosierdziem czy sprawiedliwością.

Celem publikacji jest przybliżenie czytelnikowi adhortacji apostolskiej Amoris laetitia i wyjaśnienie wątpliwości pojawiających się na tle jej rozbieżnych interpretacji. Całość książki podzielona została na dziewięć rozdziałów, z czego pierwsze siedem przedstawia w skrócie treść adhoracji, a rozdział ósmy (podzielony na osiem podrozdziałów) zawiera zwięzły komentarz do fragmentów adhoracji odnoszących się do problemu udziału małżonków żyjących w związkach nieregularnych w życiu sakramentalnym Kościoła (nn. 300-308). W rozdziale dziewiątym zamieszczono podsumowanie i wnioski. 
W rozdziale pierwszym Autor przybliża czytelnikowi dwa pierwsze rozdziały adhoracji, które mają charakter wprowadzający. Przytacza najważniejsze fragmenty, w których Papież zapoznaje czytelnika z tematyką rodziny, poczynając od jej biblijnego ujęcia - w każdym wymiarze tej instytucji. Zwraca uwagę na dostrzeżone przez Papieża zagrożenia, z którymi zmagają się współczesne rodziny, tj. osłabienie wiary, problemy socjalne, ekonomiczne, migracyjne, brak czasu.

W drugim rozdziale Autor omawia trzeci rozdział adhoracji, który został przez Papieża poświęcony istotnym elementom nauczania Kościoła na temat małżeństwa. Małżeństwo ukazane zostaje jako dar od Boga, o charakterze sakramentalnym i niezmiennie nierozerwalnym. Autor podkreśla szczególne znaczenie fragmentu nauczania Ojca świętego dotyczącego obowiązku duszpasterzy „właściwego rozeznania sytuacji”.

W rozdziale trzecim Autor przedstawia czwarty i piąty rozdział adhoracji adhortacji poświęcony miłości. Rozdziały te w zamyśle Ojca Świętego w szczególny sposób zostały zadedykowane małżonkom. Zawiera się w nich refleksja na temat miłości małżeńskiej i zagrożeń, z jakimi się ta miłość mierzy oraz roli dialogu w budowaniu wspólnoty. Papież opisuje miłość prokreatywną, podkreśla wyjątkowość miłości rodzicielskiej, dostrzega np. zagrożenia wynikające z przedwczesnego powrotu matek do aktywności zawodowej i przypomina o wartości rodziny „poszerzonej” (wielopokoleniowej).

W rozdziale czwartym ks. Góralski omawia rozdział szósty adhoracji adresowany w sposób szczególny do duszpasterzy. Poświęcony on został przedstawieniu dróg duszpasterskich prowadzących do budowania rodzin trwałych i płodnych. Wskazano tutaj na konieczność odpowiedniej formacji kapłanów, diakonów, zakonników i innych pracowników duszpasterstwa rodzin, co będzie miało przełożenie na odpowiednie przygotowanie nupturientów do roli małżonków oraz zapewnienie wsparcia w trakcie pierwszych lat życia małżeńskiego.

Następnie Autor przytacza słowa Papieża o potrzebie usprawniania pracy sądów kościelnych. Ojciec Święty dostrzega gnębiące rodzinę problemy: trudną sytuację dzieci wychowywanych w rodzinach dotkniętych rozwodem czy separacją, różnicami wyznaniowymi, 
śmiercią członka rodziny czy homoseksualizmem, przestrzegając przed tworzeniem analogii pomiędzy związkami jednopłciowymi a Boskim planem dotyczącym małżeństwa i rodziny.

W piątym rozdziale pracy Autor przybliża czytelnikowi rozdział siódmy adhoracji, dotyczący wychowywania dzieci, w świetle współczesnych zagrożeń. Papież przestrzega przed obsesyjnym kontrolowaniem dzieci, co stoi w sprzeczności z procesem dojrzewania do odpowiedzialnej wolności i autonomii. Podkreśla jednocześnie, iż rodzina jest najlepszym środowiskiem pozwalającym na przyswojenie przez dziecko zasad moralnych i jego edukacji seksualnej, nauki krytycznej oceny przekazów medialnych oraz do przekazania wiary katolickiej.

W rozdziale szóstym Autor przedstawia treść rozdziału ósmego adhoracji po to, by następnie szczegółowo skomentować go w rozdziale ósmym pracy.

W rozdziale siódmym czytelnik zapoznaje się z treścią z dziewiątego rozdziału adhoracji apostolskiej, ukazującego specyfikę duchowności wypływającej z życia rodzinnego.

Na szczególną uwagę - nie umniejszając wartości pozostałych zasługuje rozdział ósmy opracowania, w którym Autor przedstawia komentarz do nn. 300-308 dokumentu papieskiego; szczegółowo omawia najbardziej kontrowersyjne fragmenty adoracji:

- w n. 300: „Możliwa jest tylko nowa zachęta do odpowiedzialnego rozeznania osobistego i duszpasterskiego indywidualnych przypadków, które powinno uznać, że ponieważ „stopień odpowiedzialności nie jest równy w każdym przypadku, to konsekwencje lub skutki danej normy niekoniecznie musza być takie same” wraz z przypisem 336: „nawet, gdy chodzi o dyscyplinę sakramentalna, ponieważ po rozeznaniu można uznać, że $w$ danej sytuacji nie ma poważnej winy[...];

- w n. 301: „Dlatego nie można już powiedzieć, że wszyscy, którzy sq w sytuacji tak zwanej «nieregularnej», żyja w stanie grzechu śmiertelnego, pozbawieni łaski uświęcającej”;

- w n. 305, zgodnie z którym „ze względu na uwarunkowania i czynniki łagodzące możliwe jest, że pośród pewnej obiektywnej sytuacji grzechu osoba, która nie jest subiektywnie winna albo nie jest 


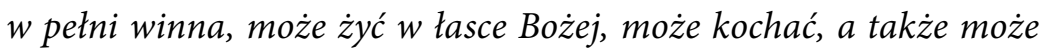
wzrastać $w$ życiu łaski i miłości, otrzymując w tym celu pomoc Kościoła" i przypisie (351) do tego fragmentu:,,w pewnych przypadkach mogłaby to być również pomoc sakramentów. Dlatego «kapłanom przypominam, że konfesjonał nie powinien być sala tortur, ale miejscem miłosierdzia Pana» (Adhort. apost. Evangelii gaudium [24 listopada 2013], 44: AAS 105 [2013], 1038). Zaznaczam również, że Eucharystia «nie jest nagroda dla doskonałych, lecz szlachetnym lekarstwem i pokarmem dla słabych» (tamże, 47: 1039)";

- w n. 79: „Stopień odpowiedzialności nie jest równy w każdym przypadku i moga istnieć czynniki, które ograniczaja zdolność podejmowania decyzji".

Autor relacjonuje wątpliwości, jakie wywołał rozdział ósmy adhoracji, a w szczególności przytoczone fragmenty. W następnym kroku przystępuje do właściwej i zgodnej z dotychczasową doktryną interpretacji słów Papieża, wskazując na wstępie, iż nie zmieniona pozostaje zasada, iż małżonkowie rozwiedzeni pozostający w nowych związkach, nie mogą przystępować do Komunii świętej, gdyż znajdują się w sytuacji, która stoi w sprzeczności z nierozerwalnością małżeństwa. Wyjaśnia, że nowością wnoszoną przez adhorację jest zwrócenie uwagi na potrzebę przyjścia przez duszpasterzy z pomocą małżonkom, o których mowa, poprzez osobiste i duszpasterskie rozeznanie. Komentując wskazaną przez Papieża w n. 301 adhoracji możliwość zaistnienia czynników łagodzących, uwalniających od winy subiektywnej („może znaleźć się w określonych warunkach, które nie pozwalaja mu działać inaczej i podjać inne decyzje bez nowej winy”) wyjaśnia, iż chodzi tu o sytuację małżonka żyjącego w związku „nieregularnym", w którym określone warunki nie pozwoliły by mu na powstrzymanie się od współżycia z współmałżonkiem, gdyż mogłoby to spowodować zaciągnięcie nowej winy. Autor przypomina podstawową zasadę, zgodnie z którą do grzeszności aktu ludzkiego nie wystarczy sama materia, a konieczna jest świadomość rozumu i wolność decyzji. Słusznie podkreśla, że ewentualne okoliczności łagodzące dotyczą nie winy zaciągniętej za rozwód, ale winy za trwanie w grzechu cudzołóstwa. Dochodzi do wniosku, iż małżonek żyjący w związku 
„nieregularnym” może przystępować do Komunii świętej, gdy nie ma grzechu ciężkiego, a z tego wnosi, iż zapewne taką właśnie sytuację miał na myśli Ojciec Święty stwierdzając, że trwanie w sytuacji „nieregularnej" nie przesądza o braku u danej osoby łaski uświęcającej.

Następnie Autor zadaje sobie pytanie, czy możliwa jest sytuacja, w której małżonek rozwiedziony żyje na sposób małżeński w nowym związku, przy braku jego subiektywnej winy lub winy niepełnej wskutek wpływu czynników łagodzących, w której to sytuacji spowiednik mógłby udzielić mu rozgrzeszenia. Poszukując odpowiedzi, przytacza nauczanie kard. E. Antonelliego ${ }^{1}$, zgodnie $z$ którym udzielenie rozgrzeszenia jest możliwe, gdy małżonkowie zobowiążą się do wstrzemięźliwości seksualnej. W podpunkcie ósmym rozdziału ósmego Autor omawia dokument biskupów rejonu duszpasterskiego Buenos Aires z dnia 5 września 2016 roku, przestrzegając przed przedstawionym w nim szerokim rozumieniem zakresu „rozeznania duszpasterskiego”.

W rozdziale dziewiątym Autor dokonuje podsumowania, skupiając się na duszpasterskim charakterze omawianej adhoracji. Podkreśla walory teologiczne, duchowe i pastoralne rozdziałów dotyczących małżeństwa. W ostatnich akapitach pracy przypomina, że pomimo sformułowań budzących wątpliwości, adhoracja nie zmienia dotychczasowej doktryny w zakresie udziału w Eucharystii katolików rozwiedzionych i żyjących w nowych związkach.

Docenić należy w szczególności spójną logikę, klarowne przedstawienie i wyjaśnienie wątpliwości oraz wyważony język, którym posługuje się Autor, dzięki czemu omawiana publikacja z pewnością posłuży pomocą duszpasterzom, katechetom i wiernym świeckim w prawidłowym rozumieniu nauczania Ojca świętego, chroniąc ich przed wyciąganiem pochopnych wniosków. Lekturę pracy polecać należy m.in. przedstawicielom mediów. Można wyrazić nadzieję, że w przyszłości Autor podejmie trud opracowania kolejnych publikacji dotyczących tej trudnej materii.

Dorota Urbanowska-Wójcińska

1 E. Antonelli, Per vivere l'„Amoris laetitia”, Milano 2016. 